\title{
Tomorrow's Ethics in a Globalizing World
}

\section{Martin Prozesky}

\begin{abstract}
The exploration of the ways ethical practice will change in the future is done in this article by means of five great transitions. They are as follows: firstly, from the ethics of obedience to an ethic of creative commitment; secondly, from a primary concern with micro-ethics to an equal and even greater concern with macro-ethics; thirdly, from a cluster of regional value systems to a cooperatively created global ethic; in the fourth place, from a conceptual base in western philosophy and theology to an academic base in the social and natural sciences; and in the fifth place, from dependence on religion in important parts of the world, including ours, to what I want to call a relationship with religion characterized by cooperative, critical and creative independence for ethics.
\end{abstract}

Keywords: ethic of creative commitment, macro-ethics, a cooperatively created global ethic, academic base in the social and natural sciences, a relationship with religion

\section{Introduction}

In speaking of ethics and morality I have in mind behaviour on the basis of values accepted as right and good, rather than the academic study of such behaviour, though I will refer to this second, academic and important meaning of the word towards the end of this article. While the emphasis will mostly be on what I see as the future of ethics, its present and past character will also receive comment. This is because I approach my subject by means of five great transitions from the present and past to what I believe the informed conscience of humankind will emphasize in the decades to come and beyond in relation to new problems. 
These transitions are as follows: Firstly, from what I shall call the ethics of obedience to an ethic involving personal, creative moral commitment and responsibility; secondly, from an age-old and important primary concern with micro-ethics to an equal and even greater concern with macro-ethics; thirdly, from a moral landscape marked by a cluster of regional value systems to a cooperatively created global ethic; in the fourth place, from an academic and conceptual base in western philosophy and theology to an interdisciplinary, academic base that also involves the social and natural sciences; and in the fifth place, from ethical dependence on religion in important parts of the world where religious observance is widespread, like South Africa and evidently also the USA, to what I want to call a relationship with religion characterized by cooperative, critical and creative independence for ethics in its relationship with religion. I shall now discuss these five great transitions in turn.

\section{From the Ethics of Obedience to an Ethic of Creative Commitment}

Cambridge religious and ethical thinker Don Cupitt has written that in our time humanity is moving from the mode of the soldier to the mode of the artist (Cupitt: 2013; see also 1995). He has in mind the sweeping change of consciousness and culture that has radically changed much, though not yet all, of the human world, as people embrace creative, responsible liberty and throw off subjection to the rule of kings, autocratic chiefs, imperialists and dictators, who all demand obedient subjects, by force if necessary.

In his own words:

The general idea is that I want to replace the ecclesiastical idea of the believer as a soldier (miles Christi) who fits into a vast institution that provides him with a complete set of authorities to obey, things to believe, laws to live by, approved rituals to follow, etc., and to replace that now outmoded disciplinarian model with a new image of the believer as the artist of his (or her) own life. He (or she) works on a blank canvas, discovering and projecting out his (or her) own lifestyle or 'spirituality'. We become who we are by finding out how we can 
best and most fully express ourselves, and be at ease in life. We should have been changing over from ecclesiastical to 'kingdom' religion during the nineteenth century. Instead, we lapsed into stifling nostalgia and neo-conservatism (Cupitt 2013).

Cupitt captures autocratic regimes with the symbol of the soldier, perhaps the best example of obedience to commands by superiors. By contrast, the artist stands for the creative freedom of which all of us are capable and which we begin to enjoy in conditions of genuine democracy.

Given my work in the fields of ethics and religion, it is the philosophers Immanuel Kant (1724-1804) and Alfred North Whitehead (18611947) whose wisdom further highlights the nature of this first great transition from the ethics of obedience to an ethic of creative commitment. Thus, in the preface to his Critique of Pure Reason, Kant would write in 1781 that, 'the present age is in especial degree an age of criticism, and to criticism everything must submit' (Kant 1933: 9, note a). In view of Kant's enormous influence on our understanding of ethics, it is obvious that for him, ethics itself must also be subjected to critical evaluation, including ethics as taught by religion.

Whitehead's wisdom is, for my purposes, best found in connection with creativity, which he described as 'the universal of universals characterizing ultimate matter of fact' (Whitehead 1978: 21). What he means is that the world we experience is governed not by emperors or despots but by a power of creative thought and action available to us all and at work throughout the universe.

What do these great thinkers imply for ethics as the doing of that which is held to be right and good? They mean that it is time for humanity to move on from the belief that we get our ethical values in a top-down way in the form of commands requiring obedience.

This is a very ancient notion. The first evidence of it that I have been able to locate is in the famous Babylonian Code of Hammurabi, compiled around 1800 BCE. A stone pillar was found on which was inscribed the Code. The top of the pillar contains a depiction of the deity Shamash, god of justice, delivering to the king the symbols of royal authority, so commissioning him to write the laws of the Code. Clearly, this is top-down mode. The message is clear enough: doing the right thing means that people must obey the king, who must obey the gods if they are polytheists and a single god if they are monotheists. 
We find the same notion deeply embedded in other cultures of the past, including ones that are influential today. Examples are the Laws of Manu in the Hindu ethical tradition and, let it be acknowledged with the same respect, in the biblical Ten Commandments. What are commandments if not a device intended for and effective in cultures in obedience mode?

The transition from obedience to creative commitment in ethics is not so much about the content of instruments like those I have mentioned, though it too is seen by many as also falling under Kant's principle of universal critical freedom. The transition is chiefly about the way we do ethics. With due respect for the guidance of top-down ethics when we humans were an unlettered lot, doubled over by the sheer demands of keeping alive and fearful of the lash of those who sat upon their thrones, those days are now ending.

They are ending in politics with the coming of genuinely democratic systems. They are coming under radical challenge in the economic sphere as challenges mount to the control of wealth by the very wealthy few, or of the very powerful few as we saw in the old Soviet Union. We have seen them happening, albeit incompletely, in important parts of religion, such as the Protestant Reformation, as in congregational forms of church government. We are seeing it in the feminist transformations of gender injustice in society and in the worlds of faith, and we have seen it in the processes of secularization as they contested old forms of religious control. And the same revolution has been happening to ethics as it too moves from obedience to creative responsibility.

It is important to understand why and how ethics is undergoing this great change of mode and, in part, also of content, a matter which is discussed in the next section. It is happening because we humans are by nature creative beings equipped with the ability to think and develop strong values for ourselves. Doing things by means of imposed power requiring obedience runs counter to the discovery of our own independent ability to think, value and act for ourselves, including the need to do so responsibly and not selfishly. That is why in modern times, especially since the European Enlightenment, so many people are discovering the top-down mode of doing things as captivity, not liberation, and simply walking away from it into the challenging but enormously enriching experience of choosing the freedom to think, believe, value and live as responsible, creative adults in partnership with our fellow adults as equal beings. In ethics this liberation leads to a growing awareness that the ethical mode of the past, still with us, cannot meet the new challenges of today and tomorrow's world. This takes us to my remaining four transitions. 


\section{From Micro-ethics to Macro-ethics}

By micro-ethics I mean doing what is right and good at an inter-personal and thus small-scale level, like telling somebody the truth, lending them a helping hand and never stealing or striking anybody. If we think for a moment of the words of the second half of the Ten Commandments, we will see that they have this inter-personal character. As an essential part of moral character-building, this is absolutely vital. It is also what we'd expect in the ethics of small-scale communities in the agricultural and pastoral periods, and, I would add, in situations where very, very few people, if any, were able to sit back and think carefully and critically about the rights and wrongs of large-scale issues in entire cultures, such as why there is poverty or whether traditional monarchies can be ethically justified.

Things are more complex in our world of increasing personal freedom and equality - the world of my first great transition. It is also an age of information with the rise of new areas of knowledge like the natural and social sciences and modern history, giving us rich new insights into the way cultures and their constituent structures work and how to change them. The result is a keen awareness of the macro forces at work in our world. These are the embedded ways things are done in whole societies and civilizations. Let me mention some examples.

There is the way power is used, whether by self-serving elites or by all the people. There is the way the means of creating wealth are owned, such as land, machinery and knowledge itself. There is the status of people, as defined by class, religion, language, gender and skin colour.

What recent experience has shown people is that these macro structures are human creations or artefacts, not brute facts that cannot be changed. For example, we have discovered that the so-called 'divine right of kings' is a self-serving myth with nothing divine about it. Many of us are discovering similar self-serving myths about the contention that men are by nature entitled to power over women.

With this in mind we can now focus on the ethics of macro-structures and forces. Its initial project is to evaluate all such structures for how well or badly they meet core ethical values like justice, respect, responsible freedom and truth. Are women really equal citizens with men in the world? Are our political structures honourable and fair towards all, or just a voting majority? Does the failure of communism mean that capitalism is ethical and if not, what 
would be? In short, the initial project of macro-ethics is the unmasking of all structures of domination and oppression.

As we saw earlier, Kant contended that religion is also subject to this project of critical ethical evaluation. This important task is, however, fraught with potential for deep misunderstanding, hostility and even conflict because it touches on things about which many people are passionate. The passion is entirely understandable, for religion, as theologian Paul Tillich once explained, is about that which concerns us ultimately. (Tillich 1957).

The problem is that people understand their ultimate concerns very differently. Let me mention just one example of the difference. For some believers, their faith and its sacred texts are seen in their entirety as divine truth and therefore, of necessity, without moral or factual blemish. At the opposite end of the spectrum there are others, no less upright, who argue with great passion that nothing in religion can be divine truth because there is no divine being. I have in mind people like Richard Dawkins and the other proponents of the new atheism (Dawkins 2006). For them, religion is entirely a human creation and just as beset with flaws as any other artefact, if not more so.

Then we find yet other people for whom religion - their own and other people's - is seen as a mixture of things that have a divine source, making them ethically perfect in their eyes, and others that are humanly created and at times anything but good. One example of the latter would be Christians who regard biblical injunctions about the subordinate place of women as gravely immoral, or who judge biblical passages condemning gay and lesbian people just as negatively, while on the other hand accepting the ethics of love taught by Christ as an ultimate good.

So the macro-ethical project of ethically interrogating religion is one that calls for the utmost sensitivity. But it is happening, and is of the greatest importance. It does immense harm to people and the structures in which they live when flawed and at times dangerous arrangements are declared by those with power and influence to be divinely authorized, and therefore unalterable. What else were reformers like Luther, Calvin, Ignatius Loyola, Muhammad and the classical Hebrew prophets doing but unmasking evils which some powerful people had deemed sacred? So the ethical criticism and transformation of religion is not new. What is new is how radical and complex the unmasking of macro-wrongs has become.

The second part of the macro-ethics is to correct what is found wrong. As a believer in the power of the good, I believe the project will succeed over 
time, but it will not be easy. Those who benefit from macro-level injustice and deception will not easily give up their spoils. But we of goodwill can take cheer. In the long run, ethics defeats empires. Whose project has won, that of Moses or that of the once mighty Pharaoh, that of Christ or that of Caesar, that of Muhammad or that of the rulers of Mecca in his day?

\section{From Provincial to Global Ethics}

My term 'the cultural geography of ethics' defines the present situation of the world's ethical traditions. They comprise a set of cultural regions in which a particular ethical tradition is dominant, for example Hindu ethics in India and the Hindu diaspora, or Christian ethics in Europe and wherever European missionaries, invaders and settlers went.

If the world were a single country, its ethical character could be called highly federal, even confederal, with a set of moral provinces each with its own, largely religious and largely autonomous, approach to ethics. One ethical province, that of the aggressive secular humanism championed by thinkers like A.C. Grayling (2013) and Richard Dawkins (2006), is not on respectful terms with the others and wants to convert them every bit as much as some of the heavily religious provinces have sought militantly to make converts of everybody if possible, and in some cases still do.

The eminent New Zealand scholar Lloyd Geering provides a helpful model of the history of ethics which will deepen our understanding of the cultural geography of ethics. He discerns three great overlapping stages, separated by two great transitions or thresholds, as he calls them (Geering 1991: 8-13, cf. Geering 1980: 29-91).

The first and earliest he calls ethnic ethics. Humankind existed as a multitude of distinct ethnic communities, defined by language, territory, religion, culture and kinship. These existed in all the habitable continents for many thousands of years. Distance, geographical barriers and at times hostilities kept them away from and ignorant of all but a few neighbouring ethnic communities. In them what we today distinguish as ethics and religion formed a seamless whole and today's secularism seems to have been unknown, in the sense that everybody followed the ethnic faith and ethic of their community.

Around 2500 years ago this age-old pattern began to change radically in what Geering calls the First Threshold. (Geering 1980: 29-48). Across Asia, 


\section{Martin Prozesky}

from the China Sea to the Aegean in a century or two, there appeared a set of remarkable individuals who offered a vision and practice of religion and ethics that transcended ethnic and other human boundaries. In China there was Confucius and Lao Tzu; in India, the Buddha and the Mahavira, in Persia, perhaps somewhat earlier, Prophet Zoroaster; in Ancient Israel the Hebrew prophets who offered a universal spiritual vision, and in Ancient Greece, somewhat later, great thinkers like Socrates, Aristotle and especially Plato, who created what might be called European philosophical ethics.

The teachings of these remarkable luminaries proved attractive enough to begin to draw people from very different ethnic societies into them, giving rise to major new, cross-cultural ethical and spiritual traditions like Vedanta, Confucianism, Buddhism and Jainism. These Geering calls the trans-ethnic traditions, and it is their further development that saw the beginnings of the two most widely spread and followed forms of trans-ethnic morality, through the lives and messages of Jesus of Nazareth and Prophet Muhammad. It is the rise and immense success of these trans-ethnic moralities and faiths that gives the world its present ethical provinces, with a few remaining ethnic moralities in Africa and elsewhere.

Geering's Second Threshold is a much more recent development, riding on the liberated intellectual power of the Renaissance, the Enlightenment, the rise of the sciences and on some features of the Protestant Reformation, like personal access to the Bible. This more recent threshold of radical change is none other than the transition Don Cupitt epitomizes as the move from the mode of the soldier to the mode of the artist.

I have already indicated some of its effects. The most important one is a growing awareness that the ethical challenges of a globalizing world cannot be handled by a set of regional or provincial moralities - Geering's trans-ethic moralities - embedded as they are in very different religious beliefs with a history of and potential for future conflict in some cases.

Globalization is making the world one country in matters of the environment, economy, trade, communications and some sporting codes like football and athletics. Each of these powerful new realities brings new and important ethical problems, from pollution to internet invasions of privacy and match-fixing. They call for a cooperative, creative project supported by people of good will in all religious faiths, and none, to build a genuinely global ethic in the form of an agreed set of core values and an agreed account of why they should be practised. 
Valuable, early work in this direction has been done by people like Hans Küng (Küng 1997) and Rushworth Kidder (Kidder 1994). It is also an emphasis in my own recent work on comparative ethics (Prozesky 2007: 98145 ), but much more needs to be done. Moreover, success in constructing a global ethic depends on whether or not the last two of my five great transitions to tomorrow's ethics take place or not. Let me turn to them now.

\section{From an Academic Base in Western Philosophy and Theology to a Multi-disciplinary Academic Base}

At least in the western countries and those academically influenced by them, like South Africa, the study of morality is mostly seen as the province of our philosophers and theologians. Nobody who has even a basic familiarity with the work of moral philosophers like Aristotle, Kant, Mill, Rawls and others can fail to be enriched by the power of their insights into the moral domain. No other discipline, in my experience, brings to that domain such sophisticated powers of analysis and explanation. The future of ethics must therefore continue to be illuminated by philosophy.

Another of the benefits philosophy brings to ethics is the fact that its primary, if not only, instrument, reason, can in principle be free of cultural and religious confinements, being a universal human capacity. Logicality is the same everywhere, like mathematics, or so we are told.

The world is of course intellectually broader than the philosophy of the west, and in the global ethics of the future we need to see other strands of this discipline at work, such as Indian, Chinese, Islamic and African.

Theology is the other discipline traditionally concerned with ethics in many parts of the west. Here too work of immense value has been done, such as the theological ethics of Karl Barth and Dietrich Bonhoeffer (Barth 1957, Bonhoeffer 2005) and their equivalents in other faith traditions like Judaism's Jonathan Sacks (Sacks 2002) and the Dalai Lama (Dalai Lama 1999). One does not have to share the beliefs of these theological ethicists to derive great ethical value from their work, because, despite very real differences in what the different faiths believe to be the source of the good, they are substantially agreed about core values like compassion, justice and truthfulness, a reality of the greatest importance for creating a global ethic by building moral partnerships on those common core values. This, of course, brings us back briefly to the quest for a global ethic. 
It is of the greatest importance that such agreed, core values exist independently in so many cultures, and perhaps in all of them, because it means that none had to be taught good, basic morals by outsiders. The various cultures can then come into a partnership for global ethics as genuine equals. In addition, what they share as basic moral values can be used to manage the important reality of their moral divergences on matters like marriage, food, the death penalty and abortion with wisdom and due respect rather than misunderstanding, hostility and even conflict.

That ethics based on the different theological beliefs of the various religions can do great good in the moral provinces where those beliefs are widely held is clear. Islamic ethics can do much more good in Indonesia, for example, than in Canada. But it is also clear that a global ethic cannot be based on the beliefs of our religions, because whatever creed or teaching any of us believes, at least two-thirds of our fellow human beings, no less honourable and informed than we are, see it as mistaken.

What we can all share is the knowledge produced by the natural and social sciences. Disciplines like neurobiology, psychology, sociology and even physics can all deepen our understanding of our moral nature, not to speak of the insights of history, literature, political studies, education and religion studies. To deal with global evils like mass poverty, corruption, climate change and exploitation we need the best possible understanding, which can only come from all relevant disciplines.

\section{From Dependence on Religion to Cooperative Independence}

The last of the transitions to tomorrow's ethics takes us back to religion. That our faith traditions are powerful carriers of moral values, that they have their own highly effective sources of moral motivation, like the promise of a coming Day of Judgement where the actions of the individual will be weighed up and judged by a deity, and that their founding figures were people of the greatest moral stature, is clear to any fair-minded and informed person.

It is, unfortunately, also clear that because of their quite fundamental differences and because there is no prospect of any one of them converting the whole world, the global ethics we need cannot have a religious foundation. The world is not going to get ethically better because the Bible says it should, or 
the Gita, the Qur'an, or the Humanist Manifesto, because most people on this planet do not see these texts as authoritative the way insiders do.

So we will have to find an inclusive basis for a global ethic elsewhere. To be fair to everybody, that base must be accessible to and authoritative for all people alike. So it must be independent of religion. Where could we find it? My proposal is that our primary source will be the human nature we all share, made known to us by the biological sciences and our own self-awareness.

When Marxism was still highly influential in parts of academia there was disdain for the idea of human nature - understood as an unchangeable, biological fact - evidently because of suspicion that the idea was a king pin of ideologies of capitalist domination. Sciences like genetics and human neurobiology have refuted this view, and we now know that we are born with certain characteristics that cannot change, like the capacity of the brain to learn languages and develop a moral sense of right and wrong, involving innate characteristics like our drives to meet our own needs and interests, and at the same time our natural concerns and feelings for others.

Such a source is open to all people equally. Supported by the findings of the natural and human sciences, along with but not limited to the fruits of religious ethics, it can be the foundation of the global ethic we must build if there is to be a worthwhile future on this planet, or even any future at all for humanity. And while it must, for the best ethical reasons of fairness and inclusivity, be independent of our religions, I reject the contentions of the new atheists that it must oppose religion, for two reasons.

Firstly, the critiques of religion provided by Dawkins (2006) and most recently by A.C. Grayling (2013) are too ill-informed about the religions they condemn to succeed in the eyes of any who really understand religion, mainly through neglect of the exceedingly important reality of religious experience, and secondly because global ethics needs the support of religious believers. They are a large majority of the world's people. That some of the things they believe and do are validly criticized by the new atheists must be conceded. That is by no means a death sentence for believers, though it is a reminder that human believing is not made infallible by being deemed the gift of the gods, which is itself an instance of human believing, and humans are not gods and not infallible.

Therefore my call is not for the ethics of tomorrow's world to be rid of religion, as the new atheists would have it be, but for religion to be more attentive to its own moral quality or lack of it, as judged by its own norms in 
the first instance and attentive also to the critique of outsiders, and in that way be the cooperative partner of ethics, recognizing it as a sovereign, independent sphere in the human project of changing this morally troubled planet of ours for the better.

Acknowledgement: This article is an edited, slightly extended version of an Inaugural Lecture on 28 August 2013 by the author, at that time as a Professor Extraordinaire in the Department of Religion Studies at the University of the Free State, Bloemfontein, South Africa. The academic, practical and financial support of the Department and its host Faculty of Theology and Religion, is gratefully acknowledged.

\section{References}

Barth, K. 1957. Church Dogmatics. Volume II/2. Edinburgh: T\&T Clark. Bonhoeffer, D. 2005. Ethics. Philadelphia: Fortress Press.

Cupitt, D. 1995. Solar Ethics. London: SCM Press.

Cupitt, D. 2013. Personal communication dated 10 September 2013.

Dalai Lama 1999. Ancient Wisdom, Modern World: Ethics for a New Millennium. London: Little, Brown and Company (UK).

Dawkins, R. 2006. The God Delusion. Boston: Houghton Mifflin.

Geering, L. 1980. Faith's New Age. London: Collins.

Geering, L. 1991. Creating the New Ethic. Wellington: St Andrew's Trust.

Grayling, A.C. 2013. The God Argument: The Case Against Religion and for Humanism. London: Bloomsbury.

Kant, I. [1781] 1933. Critique of Pure Reason. Translated by Norman Kemp Smith. London: Macmillan.

Kidder, R.M. 1994. Shared Values for a Troubled World: Conversations with Men and Women of Conscience. San Francisco: Jossey-Bass Publishers.

Küng, H. 1997. A Global Ethic for Global Politics and Economics. London: SCM Press.

Prozesky, M. 2007. Conscience: Ethical Intelligence for Global Well-Being.

Pietermaritzburg: University of KwaZulu-Natal Press.

Sacks, J. 2002. The Dignity of Difference: How to Avoid the Clash of Civilizations. London: Continuum. 
Tillich, P. 1957. Dynamics of Faith. New York: Harper \& Row.

Whitehead, A.N. 1978. Process and Reality. Corrected edition by David Ray Griffin and Donald W Sherburne. New York and London: The Free Press.

Martin Prozesky

Research Fellow

Department of Historical and Constructive Theology Faculty of Theology and Reliigon University of the Free State Bloemfontein South Africa marproz@mweb.co.za 